\title{
An estimation of snow accumulation on Svalbard glaciers on the basis of standard weather-station observations
}

\author{
Mariusz GRABIEC \\ Department of Geomorphology, Faculty of Earth Sciences, University of Silesia, ul. Będzińska 60, \\ 41-200 Sosnowiec, Poland \\ E-mail: mgrabiec@ultra.cto.us.edu.pl
}

\begin{abstract}
Winter precipitation in the form of snow is the major factor determining accumulation on Arctic glaciers. In this paper, I present a simple method to assess snow accumulation on the glaciers of Svalbard. I deduce snow accumulation from the sum of winter precipitation and the fraction of precipitation of different types at a reference weather station. The accumulation is then converted to a relevant point on the glacier, using an accumulation gradient and a location coefficient. I apply this algorithm of accumulation assessment to eight glaciers of southern and central Spitsbergen using data from 23 seasons. On the basis of measured accumulation data, the mean error of the calculated accumulation, with no distinction of precipitation types, amounted to $23 \%$. When the distinction between precipitation types is used for glaciers of southern Spitsbergen, the average error of estimation was $\mathbf{1 9} \%$. Errors result from factors influencing accumulation distribution over the glacier elevation profile (e.g. glacier topography, orography of its surroundings, precipitation inversion). Application of this accumulation algorithm may provide a crucial method of estimating mass balance for glaciers not included in permanent monitoring.
\end{abstract}

\section{INTRODUCTION}

The mass balance of Arctic glaciers is a crucial indicator of climatic change. The most important factor responsible for determining glacier mass supply is winter snow accumulation. The accumulation at the end of the winter season at any point on the glacier is a function of gains and losses of snow during this period. In winter, snowfall is the main control on glacier mass. Other factors influencing net winter accumulation (e.g. snowdrift, sublimation, melting and avalanche supply) are much less important than winter snowfall. Thus, it is assumed that the snow accumulation at a given point on a glacier is approximately equal to the sum of precipitation over a given period. The attempt at assessing the snow accumulation can be boiled down to the task of determining the total amount of precipitation in a season of accumulation. In this paper, I present a simple model for snow accumulation on Svalbard glaciers. The aim is to estimate local snow accumulation based on location, altitude, and data from a nearby permanent weather station.

Spatial distribution of the snow cover on Svalbard's glaciers has been examined in many ways on the basis of numerous field surveys, on both regional and local scales (Mikhaliov and Singer, 1975; Khodakov, 1985; Migała and others, 1988; Kohler and others, 1997; Winther and others, 1998, 2003). The variability of snow accumulation has rarely been compared to recorded precipitation at weather stations, due to weak statistical relations between such elements. According to Hagen and Liestøl (1990), the correlation coefficient between snow accumulation of austre Brøggerbreen and the sum of winter precipitation at $\mathrm{Ny}$-Ålesund station, located in the immediate vicinity of the glacier, was only 0.63. Errors in precipitation measurements are one possible reason for such weak correlation between actual mass accumulation and recorded precipitation. Errors in precipitation measurements cause the true precipitation to be overestimated by about $50 \% \mathrm{a}^{-1}$ compared with measurements from the $\mathrm{Ny}$ Ålesund station (Hanssen-Bauer and others, 1996; Førland and Hanssen-Bauer, 2000). Measurement errors become more severe with increasing wind strength and with decreasing temperature.

\section{THE ALGORITHM OF ACCUMULATION ASSESSMENT}

\section{Algorithm description}

To assess the amount of accumulation at any point on a Svalbard glacier, I used the following equation:

$$
\operatorname{acc}_{\left(I, h_{i}\right)}=\left(B_{h_{0}} L_{\mathrm{c}}\right)+\left(B_{h_{0}} L_{\mathrm{c}} \frac{\left(h_{i}-h_{0}\right)}{100} \tau\right)
$$

where $\operatorname{acc}_{\left(I, h_{i}\right)}$ is snow accumulation (mm w.e.) on a glacier situated at a distance / from the open water at a point located at a height of $h_{i} ; B_{h_{0}}$ is winter accumulation (mmw.e.) at a reference station at altitude $h_{0} ; L_{\mathrm{c}}$ is the location coefficient; and $\tau$ is the accumulation gradient, i.e. the relative accumulation increase per $100 \mathrm{~m}(\%)$.

The distance from open water is measured in a straight line between a weather station ( $I$ ) or point located in the center of the glacier equilibrium line $(d)$ and the nearest point on the coast of the open sea. Coasts composed of fjords, small bays and straits are not used to calculate distance.

$B_{h_{0}}$ is estimated on the basis of the sum of winter precipitation measured at the weather station and may be calculated by:

$$
B_{h_{0}}=K P_{h_{0}}
$$

where $P_{h_{0}}$ is winter (October-May) precipitation $(\mathrm{mm})$ at a reference station at altitude $h_{0}$, and $K$ is the efficient accumulation correction coefficient. 
Table 1. Mean values of sums of winter precipitation (OctoberMay) from the normal period 1961-90 for the Spitsbergen stations (Førland and others 1997), the distance to the open sea, and converting equations of location coefficient $\left(L_{\mathrm{C}}\right)$

\begin{tabular}{lccc}
\hline Station & $\begin{array}{c}\text { Mean values } \\
\text { of sums of } \\
\text { winter } \\
\text { precipitation } \\
\text { (October-May) }\end{array}$ & $\begin{array}{c}\text { Distance } \\
\text { from station } \\
\text { to open sea }\end{array}$ & $\begin{array}{c}\text { Location } \\
\text { coefficient } L_{\mathrm{C}}\end{array}$ \\
& $\mathrm{mm}$ & $\mathrm{km}$ & \\
& & & \\
\hline Sveagruva & 202 & 38 & $L_{\mathrm{C}}=1.9079 \mathrm{e}^{-0.017 d}$ \\
Isfjord Radio & 305 & 0 & $L_{\mathrm{C}}=2.3396 \mathrm{e}^{-0.017 d}$ \\
Svalbard Lufthavn & 119 & 50 & $L_{\mathrm{C}}=\mathrm{e}^{-0.017 d}$ \\
Longyearbyen & $134^{*}$ & 51 & $L_{\mathrm{c}}=2.3798 \mathrm{e}^{-0.017 d}$ \\
Ny-Alesund & 255 & 10 & $L_{\mathrm{c}}=1.1853 \mathrm{e}^{-0.017 d}$ \\
Hornsund & 235 & 7 & $L_{\mathrm{c}}=1.1264 \mathrm{e}^{-0.017 d}$
\end{tabular}

* Precipitation value for Longyearbyen is mean value from measurement periods and unchecked for a normal period.

The efficient accumulation correction coefficient $K$ calculates seasonal accumulation rates from the total winter precipitation. The value of $K$ is affected by two factors: error in precipitation measurements, which increases $K$, and the effect of rain, which decreases $K$. It is important to consider rain because not all winter precipitation is actually accumulated. Rain episodes included in total winter precipitation do not influence accumulation increase. Consequently, it could be assumed that accumulation is equal to the sum of real solid precipitation. $K$ can be expressed as

$$
K=\frac{k_{\mathrm{s}} P_{\mathrm{s}_{h_{0}}}}{P_{h_{0}}}
$$

where $k_{\mathrm{s}}$ is the correction factor for solid precipitation assumed to be equal to 1.85 as suggested by Førland and Hanssen-Bauer (2000), and $P_{s_{h_{0}}}$ is winter (October-May) solid precipitation $(\mathrm{mm})$ at a reference station at altitude $h_{0}$.

The $K$ coefficient is a function of solid precipitation rate in the total winter precipitation and may range from 0 to 1.85 . If only winter precipitation data with no distinction of types are available, $K$ is assumed to be equal to 1.1. This value of $K$ is valid when $60 \%$ of measured precipitation occurred as snowfall. This value is the average solid precipitation rate in the winter seasons 1975-96 at Ny-Ålesund (Førland and Hanssen-Bauer, 2000).

Precipitation is characterized as a factor of great spatial variability, due mainly to surface topography and orography. In order to determine spatial regularities in the winter precipitation distribution, the sums of precipitation at weather stations have been compared with their distances from open water. Most weather stations are located along the coast at low elevation. This allows us to assume that most weather-station data were collected at sea level. Differences in precipitation at particular stations are a function of continental influence, so the further a station is situated from open water, the lower the precipitation. Table 1 shows mean values of the sums of precipitation from October to May from the normal period 1961-90 for six Spitsbergen stations (Ny-Ålesund, Isfjord Radio, Svalbard Lufthavn, Longyearbyen, Sveagruva and Hornsund). The locations of weather-stations are shown in Figure 1. The average values of precipitation show a strong relation with



Fig. 1. Locations of weather stations at Svalbard (triangles) and glaciers (filled circles) for which the assessment of accumulation was done: 1. Ny-Ålesund; 2. Isfjord Radio; 3. Svalbard Lufthavn; 4. Longyearbyen; 5. Sveagruva; 6. Hornsund. I. Vestre Grønfjordbreen; II. Austre Grønfjordbreen; III. Fridtjovbreen; IV. Bogerbreen; V. Gløtfjellbreen; VI. Renardbreen; VII. Werenskioldbreen; VIII. Hansbreen.

distance from open water (Fig. 2). Regression analysis of the data in Table 1 made it possible to describe the long-term average of winter precipitation at Spitsbergen stations ( $p_{\mathrm{w}}$, given in $\mathrm{mm}$ ) as a function of distance from open water $(I$, given in $\mathrm{km})$ :

$$
p_{\mathrm{w}}=293.35 \mathrm{e}^{-0.0153 l}
$$

This equation explains $89 \%$ of the variation in mean winter precipitation on western and southern Spitsbergen. For the following calculations I assume that the above relationship is valid for each winter season.

The location coefficient describes the relation between the sum of winter precipitation at a site located at a given distance from the open water and precipitation at a particular station. On the basis of Equation (4), the location coefficient $L_{\mathrm{C}}$ has been calculated:

$$
L_{c}=\frac{293.35 \mathrm{e}^{-0.0153 d}}{293.35 \mathrm{e}^{-0.0153 l}}
$$

where $d$ is the distance between a glacier's equilibrium line and the open water.

The coefficient $L_{\mathrm{C}}$ has been calculated for every weather station separately. Using the conversion formula, the sum of winter precipitation will be greater at points nearer to the sea and smaller at points farther inland in comparison with sums recorded at the reference station. With a view to limiting potential errors in further accumulation assessments, meteorological points closest to the analyzed glacier have been used as reference stations.

The value of sea-level accumulation obtained using the above calculation is then converted into accumulation at a given altitude of measurement point, according to the applied accumulation gradient $\tau$. This gradient is defined as the increase in percentage of accumulation at sea level 


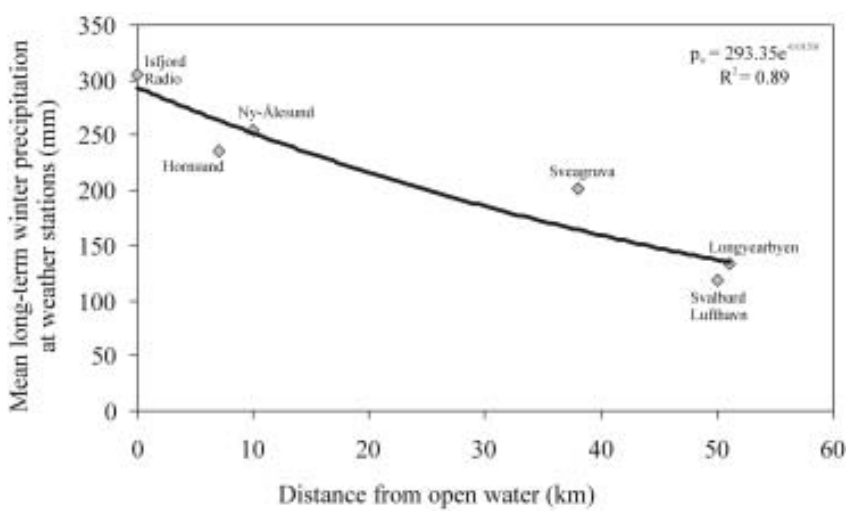

Fig. 2. Relations of mean precipitation in the winter seasons 196190 in a normal period at Spitsbergen stations with the distance to the open sea.

per $100 \mathrm{~m}$ of elevation change. This is a simplification that assumes accumulation variability is due only to changes in absolute altitude and that ignores the influence of topographic factors and possible inversion of precipitation. Elevation above sea level, however, is the most important factor for determining the accumulation variability on glaciers, hence the obtained value assumed to be used as the mean snow accumulation at a given altitude. The accumulation gradient is not a constant value but increases proportionally with increasing accumulation at sea level. In this study, the accumulation gradient $0.4-0.8$ has been tested and appears to be valid.

\section{Analysis of error assessment}

The measured accumulation was compared with elevation using a regression. The regression line shows a good approximation of normal accumulation conditions over the elevation profile. As a test of accumulation assessment, I compared the regression line with the results of calculations.

Over the examined elevation ranges, I established mean deviations from the regression line $S$ using the following method:

$$
S=\frac{\left|\int_{z_{\min }}^{Z_{\max }} A_{M}(z) \mathrm{d} z-\int_{z_{\min }}^{Z_{\max }} A_{\mathrm{R}}(z) \mathrm{d} z\right|}{Z_{\max }-Z_{\min }}
$$

when functions $A_{M}(z)$ and $A_{R}(z)$ do not intersect in the range $\left(z_{\min } ; z_{\max }\right)$, and

$$
\begin{aligned}
S= & \frac{\left|\int_{z_{\min }}^{z_{\mathrm{a}}} A_{M}(z) \mathrm{d} z-\int_{z_{\min }}^{z_{\mathrm{a}}} A_{\mathrm{R}}(z) \mathrm{d} z\right|}{z_{\max }-z_{\min }} \\
& +\frac{\left|\int_{z_{\mathrm{a}}}^{z_{\max }} A_{M}(z) \mathrm{d} z-\int_{z_{\mathrm{a}}}^{z \max } A_{R}(z) \mathrm{d} z\right|}{z_{\max }-z_{\min }}
\end{aligned}
$$

when functions $A_{M}(z)$ and $A_{R}(z)$ intersect in the range $\left(z_{\text {mini }}\right.$; $\left.z_{\text {max }}\right)$, where $A_{M}(z)$ is the linear function of evaluated accumulation vs elevation above sea level, $A_{R}(z)$ is the linear function, i.e the regression line of the measured accumulation vs elevation above sea level; $z_{\min }$ is the altitude (ma.s.l.) of the lowest accumulation measurement point located on a glacier; $z_{\max }$ is the altitude (ma.s.l.) of the highest accumulation measurement point located on a glacier; and $z_{\mathrm{a}}$ is the altitude (ma.s.l.) of intersection of functions $A_{M}(z)$ and $A_{R}(z)$.
Table 2. Precipitation data and location of glaciers selected for

\begin{tabular}{|c|c|c|c|}
\hline \multirow[t]{2}{*}{ Glacier } & \multirow[t]{2}{*}{ Season } & \multirow{2}{*}{$\begin{array}{l}\text { Sum of winter } \\
\text { precipitation at } \\
\text { reference station } \\
\text { mm }\end{array}$} & \multirow{2}{*}{$\begin{array}{c}\text { Distance } \\
\text { to sea } \\
\text { km }\end{array}$} \\
\hline & & & \\
\hline Fridtjovbreen & 1966 & $303^{*}$ & 13 \\
\hline Austre Grønfjordbreen & & & 14.5 \\
\hline Vestre Grønfjordbreen & 1967 & $345^{*}$ & 14.5 \\
\hline Bogerbreen & & & 49 \\
\hline Gløttfjellbreen & & & 65 \\
\hline Renardbreen & 1987 & $162^{\dagger}$ & 12.5 \\
\hline \multirow[t]{5}{*}{ Werenskioldbreen } & 1994 & $251^{\dagger}$ & 6 \\
\hline & 1999 & $225^{\dagger}$ & \\
\hline & 2000 & $182^{\dagger}$ & \\
\hline & 2001 & $264^{\dagger}$ & \\
\hline & 2002 & $137^{+}$ & \\
\hline \multirow[t]{11}{*}{ Hansbreen } & 1989 & $168^{\dagger}$ & 12 \\
\hline & 1990 & $320^{\dagger}$ & \\
\hline & 1991 & $332^{\dagger}$ & \\
\hline & 1992 & $256^{\dagger}$ & \\
\hline & 1993 & $199^{\dagger}$ & \\
\hline & 1994 & $251^{\dagger}$ & \\
\hline & 1995 & $244^{\dagger}$ & \\
\hline & 1996 & $350^{\dagger}$ & \\
\hline & 1997 & $200^{\dagger}$ & \\
\hline & 1998 & $253^{\dagger}$ & \\
\hline & 1999 & $225^{\dagger}$ & \\
\hline
\end{tabular}
verification of the accumulation model. Reference stations: Isfjord Radio*; Hornsund"; Svalbard Lufthavn*

For an easier comparison of errors of various glaciers and seasons, deviations have been converted into percentage values, where $100 \%$ stands for the mean measured accumulation in examined elevation profile $\left(A_{\mathrm{s}}\right)$ of a given glacier:

$$
S[\%]=\frac{S}{A_{\mathrm{s}}} \times 100 \% .
$$

\section{RESULTS}

The algorithm of accumulation assessment has been applied to eight glaciers for which snow accumulation data over the full range of glacier elevation are known. The data are valid mainly for points located along the central axes of these glaciers. The glaciers are as follows: Hansbreen, Werenskioldbreen and Renardbreen in southern Spitsbergen; Fridtjovbreen, austre and vestre Grønfjordbreen on the west coast; and Bogerbreen and Gløttfjellbreen located in the centre of the island (Fig. 1). For glaciers in the central and western part of Svalbard, data exist for the years 1966 and 1967 (Mikhaliov and Singer, 1975). For Renardbreen, data are available for 1987 (Piasecki, 1988). For Werenskioldbreen, data are available for 1994 (Jania, 1994) and 1999-2002 (P. Głowacki, unpublished data). For Hansbreen, data are available for 1989-99 (P. Głowacki, unpublished data) (Table 2). In total, 23 seasons of accumulation data for the glaciers were analyzed.

Isfjord Radio was used as the reference station for defining accumulation on glaciers of central and western Spitsbergen. For the southern region, Hornsund station was used, except for the 2001/02 season when, due to the lack of data, meteorological observations from Svalbard Lufthavn were used instead (Table 2). 
Fridtjovbreen 1966

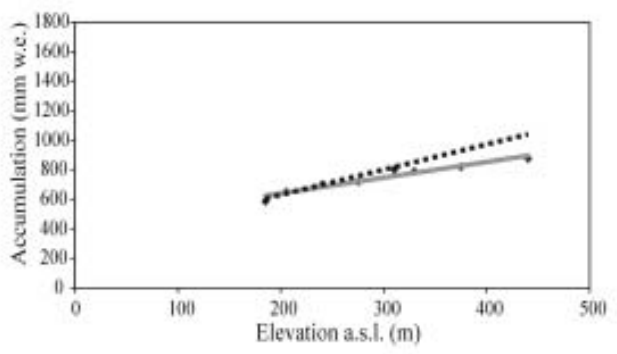

Vestre Gronfjordbreen 1966

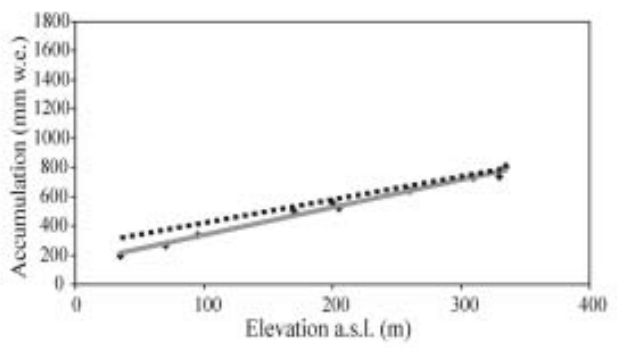

Bogerbreen 1967

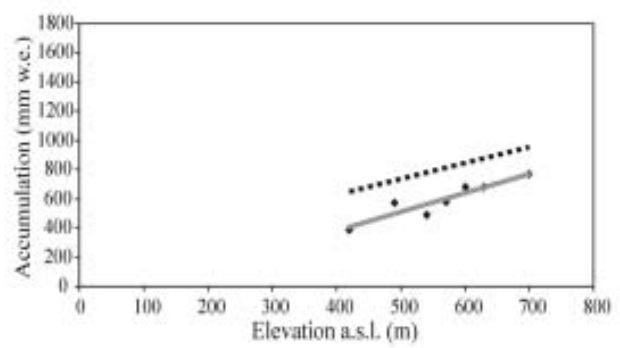

Austre Grenfjordbreen 1966

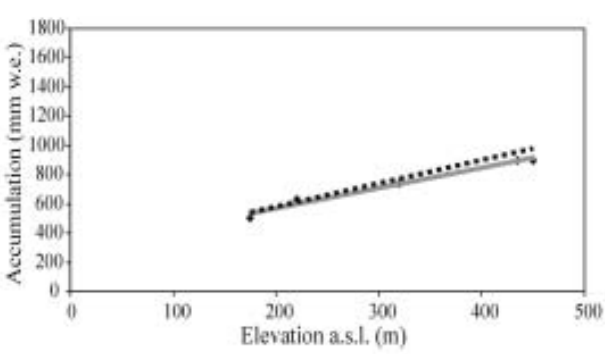

Vestre Grenfjordbreen 1967

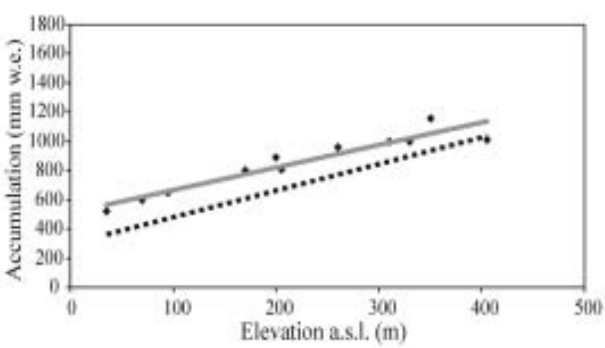

Glettfjelbreen 1967

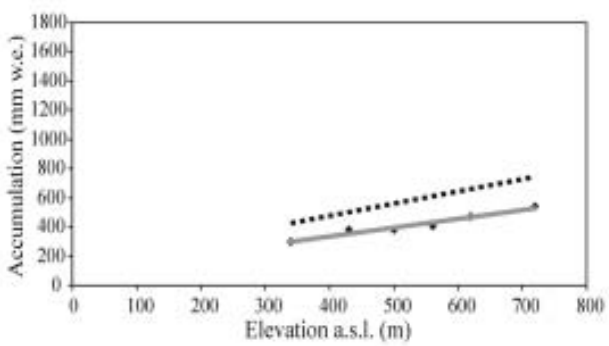

Pointed accumulation data

Estimated accumulation: $r-0.6 ; K-1.1$

Fig. 3. Observed and modeled values of accumulation on Fridtjovbreen, austre Grønfjordbreen, vestre Grønfjordbreen, Bogerbreen and Gløtfjellbreen in the years 1966-67.

Table 3. Maximum and mean errors of snow accumulation assessment for defined coefficients of precipitation correction $\left(k_{\mathrm{a}}\right)$ and precipitation gradient $(\tau)$. The smallest values of errors are in bold

\begin{tabular}{|c|c|c|c|c|c|}
\hline \multirow[t]{3}{*}{$\tau$} & \multirow[t]{3}{*}{$k_{\mathrm{a}}$} & \multicolumn{2}{|c|}{ Maximum error $S_{\max }$} & \multicolumn{2}{|c|}{ Mean error $S$} \\
\hline & & $\max$ & mean & max. & mean \\
\hline & & $\%$ & $\%$ & $\%$ & $\%$ \\
\hline \multirow[t]{5}{*}{0.3} & 1 & 109.4 & 68.9 & 65.5 & 43.0 \\
\hline & 1.25 & 95.8 & 55.2 & 58.8 & 33.0 \\
\hline & 1.5 & 82.1 & 43.5 & 56.4 & 25.5 \\
\hline & 1.75 & 94.8 & 41.1 & 82.4 & 25.7 \\
\hline & 2 & 126.6 & 45.5 & 108.5 & 31.0 \\
\hline \multirow[t]{5}{*}{0.4} & 1 & 98.4 & 57.9 & 60.4 & 36.1 \\
\hline & 1.25 & 82.5 & 43.0 & 50.5 & 26.5 \\
\hline & 1.5 & 102.0 & 39.5 & 79.2 & 25.5 \\
\hline & 1.75 & 140.3 & 46.4 & 109.1 & 31.4 \\
\hline & 2 & 175.5 & 58.1 & 138.9 & 41.8 \\
\hline \multirow[t]{5}{*}{0.5} & 1 & 87.6 & 47.7 & 55.4 & 30.1 \\
\hline & 1.25 & 96.2 & 38.6 & 68.4 & 24.3 \\
\hline & 1.5 & 140.9 & 44.8 & 102.0 & 29.9 \\
\hline & 1.75 & 185.7 & 58.7 & 135.7 & 41.3 \\
\hline & 2 & 230.4 & 74.2 & 169.4 & 54.5 \\
\hline
\end{tabular}

\section{Snow accumulation assessment based on precipitation data with no distinction of precipitation types}

When only the sum of winter precipitation at weather stations is available, the efficiency accumulation correction coefficient $K$ is assumed to be a constant value equal to 1.1. The snow accumulation was estimated using the accumulation gradient $\tau$ in a range $0.4-0.8$ (Table 3). The lowest error of accumulation assessment was obtained with the application of $\tau=0.6$. The mean error of accumulation estimation for analyzed glaciers in that case amounted to $23 \%$. Average errors range between $4 \%$ (Werenskioldbreen 2002) and $43 \%$ (Hansbreen 1989), with a median value of $16 \%$ (Table 4). The full results of accumulation estimation are presented in Figures 3-6.

\section{Snow accumulation assessment based on precipitation data with distinction of precipitation types}

The procedure presented below has been applied only to glaciers on southern Spitsbergen (Hansbreen, Werenskioldbreen and Reanardbreen) where it is possible to distinguish solid precipitation using data from Hornsund station. I assumed that all precipitation on days with an average 
Werenskioldbreen 1994

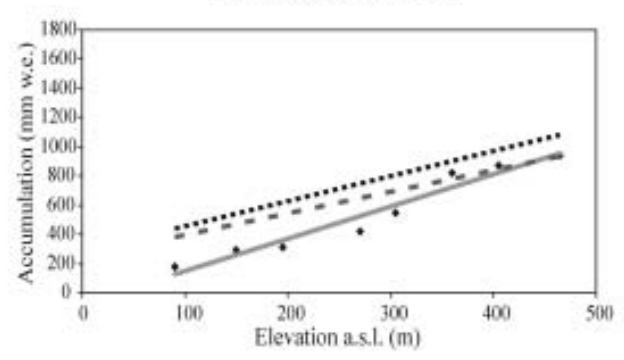

Werenskioldbreen 2000

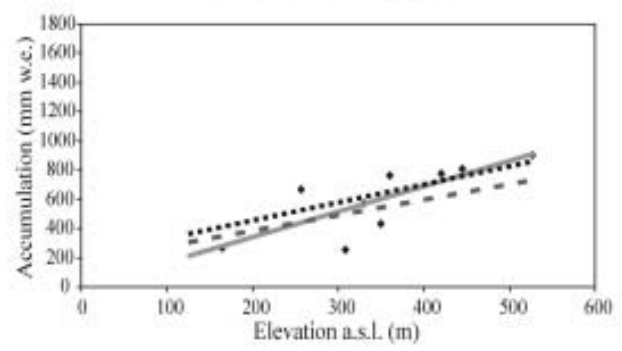

Werenskioldbreen 2002



- Pointed accumulation data

Accumulation regression line to the elevation as.

..... Estimated accumulation: $r=0,6 ; K=1.1 \quad$ - - Estimated accumulation: $r=0,6 ; K$ - variable values acconding to Ec uation (3)
Werenskioldbreen 1999

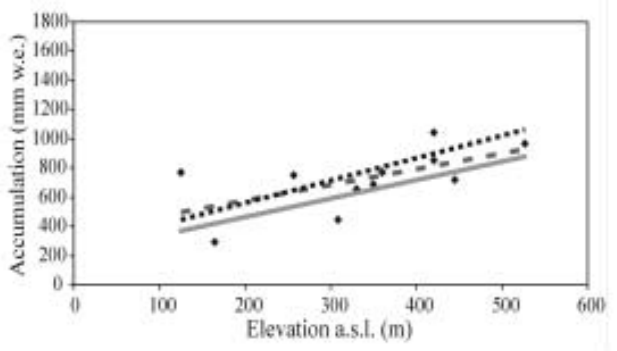

Werenskioldbreen 2001

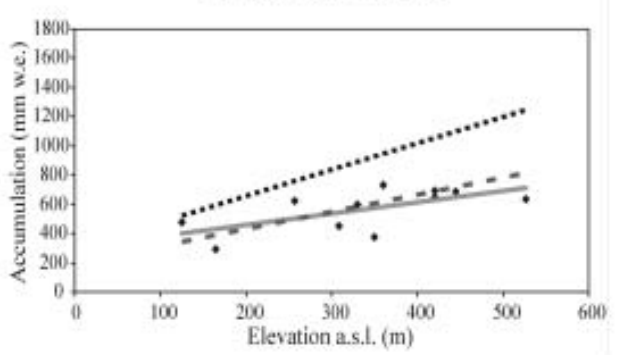

Renardbreen 1987

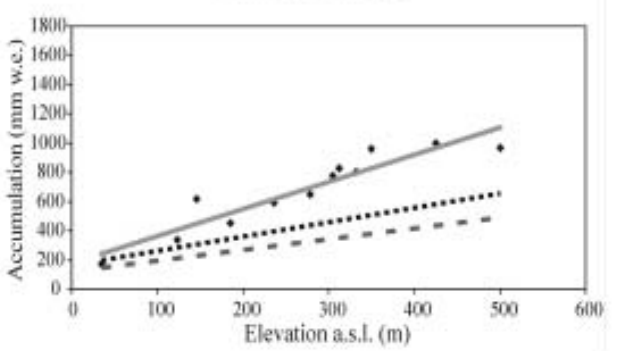

Fig. 4. Observed and modeled values of accumulation on Werenskioldbreen in 1994 and 1999-2000 and Renardbreen in 1987.

Table 4. Values of coefficients $k_{\mathrm{a}}$ and $\tau$ assuming optimum accumulation assessment. The best-matched values of coefficients in each investigated season are in bold

\begin{tabular}{|c|c|c|c|c|c|c|c|}
\hline \multirow[t]{2}{*}{ Glacier } & \multirow[t]{2}{*}{ Season } & \multicolumn{2}{|c|}{$\tau=0.3$} & \multicolumn{2}{|c|}{$\tau=0.4$} & \multicolumn{2}{|c|}{$\tau=0.5$} \\
\hline & & $\begin{array}{c}\text { Mean error } \\
\%\end{array}$ & $k_{\mathrm{a}}$ & $\begin{array}{c}\text { Mean error } \\
\%\end{array}$ & $k_{\mathrm{a}}$ & $\begin{array}{c}\text { Mean error } \\
\%\end{array}$ & $k_{\mathrm{a}}$ \\
\hline Renardbreen & 1987 & 23.5 & 2 & 13.6 & 2 & 6.8 & 2 \\
\hline \multirow[t]{4}{*}{ Werenskioldbreen } & 1994 & 20.0 & 1.5 & 12.5 & 1.25 & 13.2 & 1.25 \\
\hline & 1999 & 2.8 & 1.75 & 5.7 & 1.25 & 8.1 & 1.25 \\
\hline & 2000 & 6.7 & 1 & 9.0 & 1.5 & 10.0 & 1.25 \\
\hline & 2001 & 2.6 & 1.5 & 13.4 & 1 & 29.5 & 1 \\
\hline \multirow[t]{11}{*}{ Hansbreen } & 1989 & 31.0 & 2 & 20.9 & 2 & 10.8 & 2 \\
\hline & 1990 & 8.5 & 1.5 & 8.6 & 1.5 & 2.1 & 1.25 \\
\hline & 1991 & 6.6 & 1.75 & 7.0 & 1.75 & 5.2 & 1.5 \\
\hline & 1992 & 20.4 & 2 & 17.5 & 1.75 & 15.8 & 1.5 \\
\hline & 1993 & 23.4 & 2 & 12.2 & 2 & 1.1 & 2 \\
\hline & 1994 & 33.0 & 1.75 & 17.1 & 1.5 & 15.9 & 1.25 \\
\hline & 1995 & 17.7 & 2 & 15.0 & 1.75 & 12.6 & 1.5 \\
\hline & 1996 & 16.4 & 1 & 19.1 & 1 & 34.7 & 1 \\
\hline & 1997 & 28.0 & 2 & 17.9 & 2 & 8.6 & 2 \\
\hline & 1998 & 21.7 & 2 & 10.2 & 2 & 1.2 & 2 \\
\hline & 1999 & 24.0 & 2 & 12.9 & 2 & 1.8 & 2 \\
\hline Mean error & & 17.9 & & 14.5 & & 11.1 & \\
\hline
\end{tabular}


Hansbreen 1989

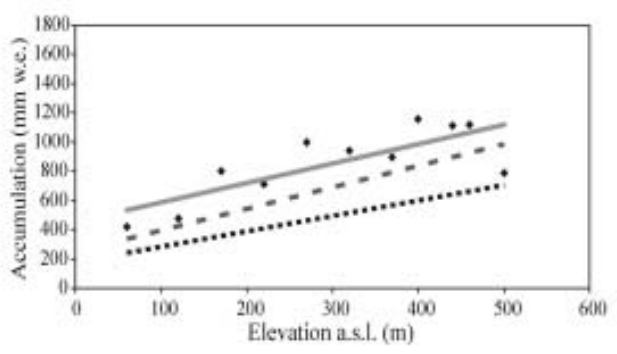

Hansbreen 1991

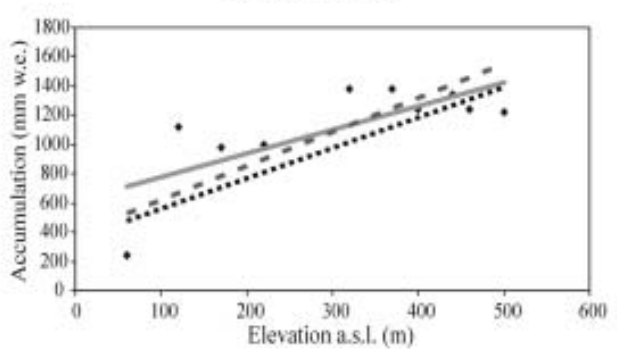

Hansbreen 1993

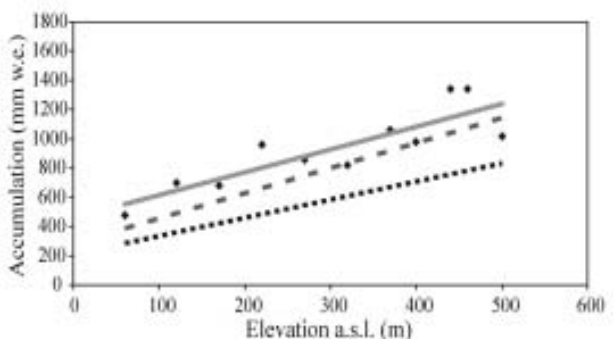

Hansbreen 1990



Hansbreen 1992

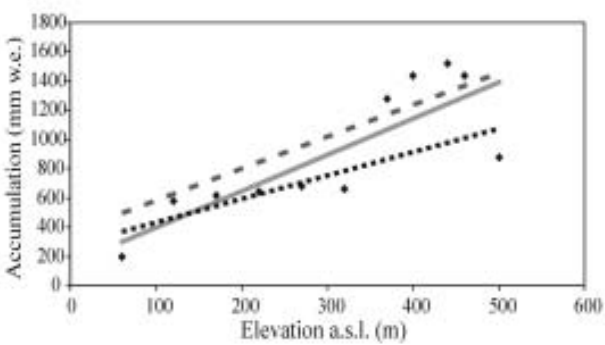

Hansbreen 1994



Pointed accumulation data
...... Estimated accumulation: $r-0,6 ; K-1.1$

Fig. 5. Observed and modeled values of accumulation on Hansbreen in the years 1989-94.

temperature $\leq 0.5^{\circ} \mathrm{C}$ was snow (after Førland and HanssenBauer, 2000). I used an accumulation gradient of $\tau=0.6$, which was determined as outlined above. The results of the accumulation assessment and the errors are presented in Table 4 and Figures 4-6. Using this method, the mean error of the accumulation estimation for the glaciers is $7 \%$ lower than the results of assessment using the sum of winter precipitation only.

\section{DISCUSSION}

The processes that lead to variations in snow accumulation over glacier surfaces are one of the reasons for the accumulation assessment errors. The algorithm does not explain variations in accumulation related to, for example, glacier topography, orography of the surroundings, snowdrift and precipitation inversion. These influences have a noticeable effect in the upper part of Hansbreen. In many seasons, the snow accumulation measured at $500 \mathrm{ma.s.l}$. was substantially smaller than that measured at a stake located $\sim 50 \mathrm{~m}$ lower. Hansbreen also has an asymmetric accumulation distribution, with greater accumulation on the western side of the glacier than on the eastern side (Jania, 1994). This pattern is common on glaciers oriented perpendicular to prevailing winds (e.g. Bogerbreen and Bertilbreen; cf. Gus'kov, 1983; Gus'kov and Troitskiy, 1984, 1985, 1987). This leads to significant differences in accumulation across the glacier at the same altitude.

The errors of estimation could also be caused by microrelief of the glacier's surface that contributes to snow accumulation (concave forms) or erosion (convex forms). Intensive redistribution of blowing snow out of the convex form has been observed on land-based glaciers fronts (e.g. Werenskioldbreen). In such cases, the algorithm will overestimate accumulation.

Other sources of error arise from approximations and assumptions. For the calculation of the location coefficient $L_{c}$, the glacier has been considered as a point object. As a result of this simplification, the distance from open water has been measured between a point located in the center of the glacier equilibrium line and the nearest point on the coast of the open sea. This could cause substantial errors where glaciers extend long distances from the sea coast towards the center of the island. One may consider a hypothetical glacier terminating in the open sea, the most distant point of which is located $20 \mathrm{~km}$ from the open water. The difference in the sum of winter accumulation at sea level between those two extreme points of the glacier, calculated on the 
Hansbreen 1995

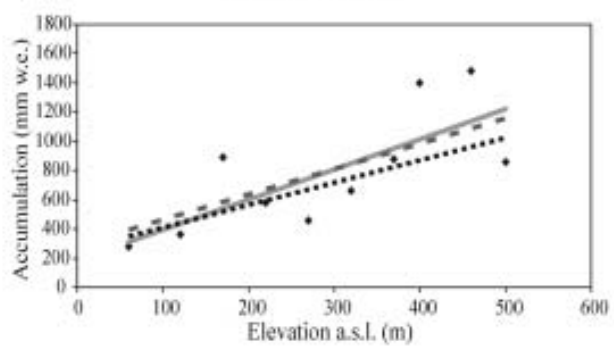

Hansbreen 1997



Hansbreen 1999

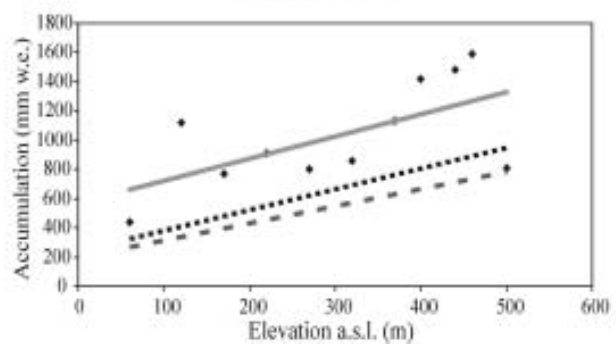

Hansbreen 1996

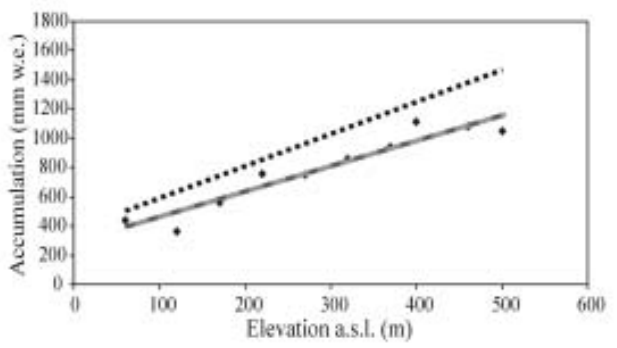

Hansbreen 1998

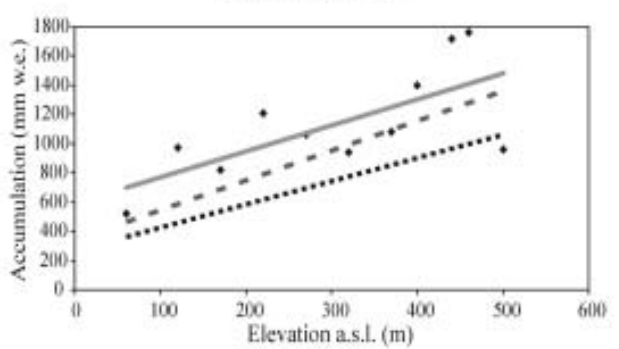

- Pointed accumulation data

_- Accumulation regression line to the elevation a.s.t.

...... Estimated accumulation: $\mathrm{t}=0.6 ; \mathrm{K}=\mathrm{1} . \mathrm{I}$

- - Estimated accumulation: $t=0.6$ : $K$ - variable values according to Equation (3)

Fig. 6. Observed and modeled values of accumulation on Hansbreen in the years 1995-99.

basis of Equation (4), amounts to $26.4 \%$. Applying the constant distance to the open water for every point on the glacier's surface, the accumulation on sites located nearest to the sea is underestimated, whereas the accumulation at the most distant points is overestimated.

The accuracy of the efficient accumulation correction coefficient $(K)$ is determined by the quality of precipitation data. The $K$ coefficient is dependent upon the solid precipitation rate in relation to the total winter precipitation. If there are no data on precipitation type, any approximation (e.g. use of temperature criterion or constant solid precipitation rate) would be a source of error. Additionally, the correction factor for solid precipitation $\left(k_{\mathrm{s}}\right)$ gives only a rough approximation of the true value of precipitation.

The observed accumulation gradients $\tau$ are not constant in space and time as has been assumed in this study. The $\tau$ factor on Hansbreen in the years 1989-99 ranged from 0.41 to 1.04 . The differences between the $\tau$ value applied in the accumulation assessment $(\tau=0.6)$ and the observed accumulation gradient could result from snow distribution disturbances on glaciers discussed above.

\section{CONCLUSIONS}

The results show a simple way to estimate accumulation for any point on Spitsbergen glaciers. The proposed evaluation procedure is mainly intended for use on western and central Spitsbergen. This is because insufficient meteorological data are available from the eastern part of the island and because of difficulties in verifying the accumulation approximation on glaciers of eastern Spitsbergen.

The minimum requirements for the accumulation estimation are the sum of winter precipitation at the nearest weather station and the location of the analyzed site on a glacier, i.e. distance from open water and elevation. The results of accumulation assessment are closer to actual values when the sum and rate of solid precipitation have been applied. Precipitation type is the most important factor determining snow accumulation.

The application of the presented algorithm allows for calculation of the accumulation on glaciers of central and southern Spitsbergen with an accuracy of 19-23\%. The errors result from the exclusion of factors disturbing accumulation distribution in the elevation profile (e.g. glacier topography, orography of the surroundings, precipitation inversion) as well as assumptions and approximations. The focus of future work will be centered on the reduction of errors.

The application of my accumulation algorithm may provide a crucial element of mass-balance evaluation for glaciers not included in permanent monitoring. 


\section{ACKNOWLEDGEMENTS}

I thank J. Jania for inspiring me to take up this topic. I also thank P. Głowacki (Polish Academy of Sciences) for making available mass-balance data of Hansbreen and meteorological data from Hornsund station, and I. Hanssen-Bauer and an anonymous reviewer for valuable comments on the manuscript. A. Lewis and K. Tomala kindly corrected the English. This research was supported by the Committee of Scientific Research, Poland (KBN) under grant No. 6 P04E 00821.

\section{REFERENCES}

Førland, E.J. and I. Hanssen-Bauer. 2000. Increased precipitation in the Norwegian Arctic: true or false? Climatic Change, 46, 485-509.

Førland, E.J., I. Hanssen-Bauer and P.Ø. Nordli. 1997. Climate statistics and longterm series of temperature and precipitation at Svalbard and Jan Mayen. DNMI Rapport 21/97 Klima. Oslo, Norsk Meteorologisk Institutt.

Gus'kov, A.S. 1983. Vodno-ledovyy balans lednikov Shpitsbergena v 1979/80 balansovom godu [The water-ice balance of Spitsbergen glaciers in the $1979 / 80$ balance year]. Mater. Glyatsiol. Issled. 46, 136-139.

Gus'kov, A.S. and L.S. Troitskiy. 1984. Vodno-ledovyy balans lednikov Shpitsbergena v 1980/81 i 1981/82 balansovykh godakh [Water-ice balance of Spitsbergen glaciers in the 1980/81 and 1981/82 balance years]. Mater. Glyatsiol. Issled. 51, 247-250.

Gus'kov, A.S. and L.S. Troitskiy. 1985. Balans massy lednikov Shpitsbergena $v$ 1982/83 balansovom godu [Mass balance of Spitsbergen glaciers in the 1982/83 balance year]. Mater. Glyatsiol. Issled. 54, 210-213.

Gus'kov, A.S. and L.S. Troitskiy. 1987. Vodno-ledovyy balans lednikov Shpitsbergena v 1983/84 balansovom godu [Water-ice balance of the glaciers of Spitsbergen in the 1983/84 balance year]. Mater. Glyatsiol. Issled. 59, 138-139.
Hagen, J.O. and O. Liestøl. 1990. Long-term glacier mass-balance investigations in Svalbard, 1950-88. Ann. Glaciol., 14, 102-106.

Hanssen-Bauer, I., E.J. Førland and P.Ø. Nordli. 1996. Measured and true precipitation at Svalbard DNMI Rapport. 31/96 Klima. Oslo, Norsk Meteorologisk Institutt.

Jania, J. 1994. Field investigations during the glaciological expeditions to Spitsbergen in the period 1992-1994: interim report, Katowice, University of Silesia. Faculty of Earth Sciences, Department of Geomorphology.

Khodakov, V.G. 1985. Sniezhnyj pokrov. In Kotlyakov, V.M., ed. Glyatsiologiya Shpitsbergena [Glaciology of Spitsbergen]. Moscow, Nauka. Akademiia Nauk SSSR, 35-46.

Kohler, J., J. Moore, M. Kennett, R. Engeset and H. Elvehøy. 1997. Using ground-penetrating radar to image previous years' summer surfaces for mass-balance measurements. Ann. Glaciol., 24, 355-360.

Migała, K., J. Pereyma and M. Sobik. 1988. Akumulacja śnieżna na południowym Spitsbergenie [Snow accumulation in southern Spitsbergen]. In Jania, J. and M. Pulina, eds. Wyprawy polarne Uniwersytetu Ślaskiego 1980-1984 [The Silesian University's polar expeditions 1980-1984]. Katowice, Uniwersytet Ślaski, 4863. (Prace Naukowe Uniwersytetu Ślaskiego w Katowicach 910.)

Mikhaliov, V.I. and E.M. Singer. 1975. Pitanie lednikov. In Oledeneniye Shpitsbergena (Sval'barda) [Glaciation of Spitsbergen (Svalbard)]. Moscow, Nauka. Akademiia Nauk SSSR, 106-152.

Piasecki, J. 1988. Akumulacja i ablacja na lodowcach Scott i Renard w 1987 r. (Poł. Bellsund, Spitsbergen) [Accumulation and ablation on Scott and Renard glaciers in 1987 (South Bellsund, Spitsbergen)]. In Jahn, A., J. Pereyma and A. SzczepankiewiczSmyrka, eds. XV Sympozjum Polarne: Stan Obecny i Wybrane Problemy Polskich Badań Polarnych [15th Polar Symposium, General Status and Selected Problems in Polish Polar Research]. Wroclaw, Uniwersytet Wroclawski, 242-253.

Winther, J.-G., O. Bruland, K. Sand, А. Killingtveit and D. Marechal. 1998. Snow accumulation distribution on Spitsbergen, Svalbard, in 1997. Polar Res., 17(2), 155-164.

Winther, J.-G. and 7 others. 2003. Snow research in Svalbard - an overview. Polar Res., 22(2), 125-144. 